\title{
Trade and Economic Growth: The Case of India
}

\author{
Simran Sethi*
}

\begin{abstract}
The objective of this paper is to investigate the short run as well as long run relationship between GDP, exports and imports for India using annual data from 1982 to 2016. Through this paper, I examine the four main hypotheses regarding the relation between exports, imports and economic growth. The first one is export-led growth hypothesis, the second one is the import-led growth hypothesis, the third one is the growth-led exports and lastly, the growth-led imports hypothesis. The Johansen's cointegration is used to examine the long term relationship and empirical results indicate that there is a long run relationship between GDP, exports and imports. The short term relationship is measured using the Granger causality test and the statistical results suggest unidirectional causality from GDP to exports and GDP to imports in conformity with the growth-led exports and growth-led imports hypothesis respectively.
\end{abstract}

Keywords: Economic growth; Exports; Imports; India; Cointegration, Granger causality.

\subsection{Introduction}

The inclination for the study comes from the varied findings on the relationship between trade and economic growth. The significance of trade has grown since the 1990s as India moved towards import liberalisation, export promotion and a more open economy. There are four main hypotheses with reference to the relation between imports, exports and economic growth. The first one is the export-led growth hypothesis which states that growth can come only through increasing the volume of exports of the country. The second one is the import-led growth hypothesis which suggests that an increase in imports, for example highly technological goods can bring economic growth through knowledge spill overs and increased productivity.

*Assistant Professor, Department of Economics, Hansraj College, University of Delhi, Delhi, India. (Email id: simran.dse@gmail.com) 
The next one is the growth-led exports hypothesis, which indicates that growth is an endogenous process and only after reaching certain level of development, the country should start exporting. The growth-led imports hypothesis argues that imports increase as the economy becomes economically more advanced.

Over the years India's trade policy has undergone significant changes. After India gained Independence, the trade policy was highly inward looking and based on import substitution industrialisation. However, this resulted in inefficiency, prevented competition and restricted imports. In 1970s and early 1980s several export promotion measures were introduced but the quantitative restrictions remained intact protecting domestic industry from foreign competition. It was only in the second half of $1980 \mathrm{~s}$ when several liberalisation measures were undertaken based on the recommendations of the Committee on Import Export Policies and Procedures (Chairman: P.C. Alexander, 1978) and the Committee on Trade Policies (Chairman: Abid Hussain, 1984). The Alexander Committee suggested the simplification of import licensing procedure and a framework involving a shift in the emphasis from "control" to "development". The Abid Hussain Committee recommended "growth led exports" rather than "exports led growth" and focussed upon the need for harmonisation of foreign trade policies with other economic policies arguing for a phased reduction of effective protection (Kapila, 2004). However, despite these changes the India's trade regime continued to be based on licensing and very high level of tariffs. It was only after the 1991 crisis, wide ranging reforms were introduced. The exchange rate system changed from fixed exchange rates to managed floating. Import tariffs were reduced from as high as $300 \%$ to anywhere between $5 \%$ to $35 \%$. Quantitative restrictions on most of the products were removed (Srinivasan, 2001).

The objective of the paper is to empirically test the relationship between exports, imports and economic growth. Through this paper, I examine the four relations: exportled growth, imports-led growth, growth-led exports and growth-led imports for India using the annual data from 1982 to 2016. The remaining paper is structured as follows. Section 2 gives the theoretical background; section 3 presents the literature review; section 4 describes the trade policy in India; the research methodology is given in section 5 ; empirical results are discussed in section 6 , and the last section concludes.

\subsection{Theoretical Background}

\subsection{Trade-led growth}

Advocates of International trade theory argue that trade between countries promote economic growth. David Ricardo in 1817 explained that if countries specialise 
in the good in which they have a comparative advantage, that is in which they face the smallest opportunity costs and thus are most efficient. Both countries can be made better off as the world production and hence world consumption increases with trade than without it. His model is consistent with the export led growth hypothesis. In the Heckscher-Ohlin model, comparative advantage is based on differences in factor endowment across countries. A country has comparative advantage in the good which is intensive in the factor with which it is relatively well endowed. For example, if we compare India and US, India is relatively well endowed with labour and US with capital. Hence, India will face comparative advantage in labour intensive goods and US in capital intensive goods. The $\mathrm{H}-\mathrm{O}$ model demonstrates that when countries move to free trade; they will experience an increase in aggregate efficiency. The change in prices will cause a shift in production of both goods in both countries. As a whole, both countries will be better off by exporting the goods that are relatively intensive in its abundant factor of production and import goods that are intensive in its scarce factor of production (Krugman, 2015). According to these two theories, countries are better off with trade than without it whether it's based on productivity differences (Ricardian model) or differences in resources (Heckscher-Ohin model) across countries (Krugman, 2015).

\subsubsection{Export led growth hypothesis}

Increase in exports has various advantages such as knowledge and technology spillovers. As the firms need to compete with the foreign companies they try to produce high technology goods with better characteristics to survive in the world markets. Thus, companies will invest in high-tech products which would lead to a technological spillover effects within the country and would eventually increase GDP. Another benefit is that when countries start to export, they produce different varieties of their product, which would expand their production and would bring more employment to the market. Trade can provide foreign exchange, which could be used to import intermediate goods for production. Amongst other benefits are: more efficient resource allocation, economies of scale, greater utilization of capacity. According to the Ricardian model of trade, each country specialises in the product in which it has comparative advantage. As both countries produce the goods in which they are relatively more efficient, the world production is higher relative to autarky. This is consistent with export-led growth type of framework.

\subsubsection{Import led growth hypothesis}

According to Import led growth hypothesis, increase in imports would increase GDP of the country. Since most of the countries do not possess all the resources, they 
would need to import those from foreign markets in order to complete the production cycle. In this case the imports mainly consist of intermediate goods, obtained to be used in production. Another medium through which imports can promote economic growth is through the import of high technological products that would bring the country knowledge spillovers and would increase productivity. This in turn improves production process and brings gains to the economy.

\subsection{Growth led trade}

Some economists question the validity of trade led growth and propose that economy's GDP can grow only from forces originating within the country itself. This is the so called endogenous growth theory. In a paper Lucas (1988) explains the effects of training on the economic performance. The worker can either work or attend training. The effects of the training will come with a lag, as the worker needs time to obtain the knowledge and also for the time of the educational process, he/she will not contribute to the production process. However, once the knowledge is obtained the worker will increase the quality of his/her work, which in general will increase the productivity and thus lead to economic growth. In another model by Romer (1989), represents a model to how would new inventions affect growth. In the model, the agents have free access to previous discoveries. In the model there are three sectors - sector producing the final output, machinery producing one and invention sector. Each of the inventions is unique and translated into new capital good. Thus, the capital stock increases. The invention to the production chain will increase the output (due to optimisation of the production process and reduction in wastage of resources) and thus will lead to economic growth. Endogenous growth theories suggest that change in political frameworks can support some of the channels for achieving economic advance. For example, if a government raises its subsidies to worker's education, R\&D expenditure or support for research centres and university this may lead to faster economic growth in the country.

\subsubsection{Growth led exports}

After a country reaches certain level of economic development, satisfies demand in its domestic market, it can start exporting its products. According to the 'New New Trade theory' by Melitz (2003), only high productivity firms can export as they can bear the costs of entering the new markets along with some additional costs such as trade permissions, open currency accounts, transport costs etc. Growth in the country increases productivity and hence exports. In the Heckscher-Ohlin model, trade in goods is a substitute for trading in factors of production. With the assumption of identical technology and capital and labour being inter-sectoral but not internationally mobile, 
free trade results not only in equalization of output prices but also factor prices. This supports the idea of growth- led exports; suggest a causal relationship from country's endowments and productivity towards export. After the country has satisfies its national market, it would export the excess goods, as also it would export a country-specific good, which is rare or scarce in other countries.

\subsubsection{Growth led imports}

Another possible relationship between imports and GDP growth is that as the GDP grows consumers prefer to consume a greater variety of goods and services. And this leads to increase in import demand. Consumer's love of variety can provoke increased demand for foreign goods. Once the GDP has grown enough to provide consumers with the ability to afford such goods, the imports would increase. Since most of the countries do not possess all the resources all the resources for their economies to grow, they must import to those resources though international trade. The growth-led imports can be explained, as the countries economically grow over time, they may show increased demand for consumption, which can only be satisfied through an increased volume of imports.

\subsection{New Trade Theory and New New Trade Theory}

In 1980's researchers incorporated models based on imperfect competition and increasing returns to scale. Using the monopolistic competition model based on the ideas of Robinson and Chamberlin (as cited in McDermott, 2011) and later Dixit and Stiglitz (1977), Helpman and Krugman (1985) made seminal contributions in the area of The New Trade Theory. Despite identical technologies and factor endowments, countries could gain from trade due to economies of scale internal to the firm. Consumers are better off as they get to consume at a lower price and wider variety of goods and services. The new trade theory also explains the intra industry trade, which is not explained by the classical or the neoclassical model. However, it fails to explain why within narrowly defined industries, firms differ with respect to their size and productivity; nevertheless they coexist; some firms within a sector do trade and others do not; and there is growing intra-firm trade as well. Additionally, the model does not explain which firms drop out of the market given that all firms are identical with respect to their technology. Also regarding productivity improvements and thus growth implications of countries, the model's explanatory power is rather poor: despite the occurring selection and scale effects, there is no change in the average productivity on the aggregate induced by trade liberalisation when firms use the same technology before and after liberalisation. This is explained by the 'New New Trade Theory' given by 
Melitz in 2003. It is able to explain the selection process induced by trade liberalisation. Heterogeneity of firms itself is explained by attributing a distinct productivity level to each individual firm. In the closed economy model, only the most efficient firms are able to survive in the domestic market. With trade, productivity threshold for entering the domestic market is moved up and firms at the end of the productivity spectrum are forced to exit. Just like the selection effect works in the domestic market, in the same way it works in the world markets. Only the most efficient firms earn enough extraprofits by exporting to bear the additional entry costs to each of the foreign markets. The country gains from the improvement in overall productivity. With trade, the domestic market share of for each domestic firm drops due to the foreign competitors - the least efficient firms exit. The most productive, however, are compensated by gaining access to the foreign market. In sum, there is a shift of market shares in favour of more productive firms and thus a direct effect of trade liberalisation on aggregate productivity.

\subsection{Literature Review}

There are many empirical studies to analyse the relation and causal directions of trade and economic growth. However the empirical findings give mixed results. Makki (2004) examines the cross sectional data of a sample of 66 developing counties over three decades, results indicate that FDI and trade contribute significantly towards advancing economic growth in developing countries. The empirical results show that FDI interacts positively with trade and stimulates domestic investment. The contribution of FDI to economic growth is enhanced by its positive interaction with human capital and sound macroeconomic policies and institutional stability. In another paper, Dritsakis (2006) investigates the relationship between exports and economic growth in the three of the largest exporting countries in the world, European Union, US and Japan. The Granger causality results indicate that exports have a causal effect on the development process for the countries of European Union, USA, while there is no causal relationship between the examined variables for Japan. Bhattacharya \& Bhattacharya (2016) use the panel data technique to study the relationship between export and import of goods and services and economic growth per capita for the BRICS. The study concludes that the GDP and trade of BRICS is tied together and thus supports export oriented policies of these nations. Frankel, Romer and Cyrus (1996) examine the role for openness in explaining the growth in East Asian Economies. They correct for simultaneous causality between growth and trade, and their empirical findings indicate that the effect of openness on growth is even more robust when corrected for the endogeneity of openness than in standard OLS estimates. 
In the individual country studies, Matadeen, Matadeen and Seetanah (2011) analyse the relationship between trade liberalization and economic growth in Mauritius, using bi-annual data for the period 1989-2009, through a Vector Error Correction Model (VECM). Empirical findings show significant positive links both in the long-run and the short-run, indicating that openness is an important engine of economic growth in the island. Similarly, using the data for Australia over the period of 1965-2010, Muhammad, Mohammad and Abdul (2012) investigate the relationship between financial development, international trade and economic growth. They employ the ARDL bounds testing approach and the findings of the study confirm the long run relationship among the variables. The results show that financial development, international trade and capital are the drivers of economic growth both in short run as well as in long run. The feedback effect exists between international trade and economic growth. Financial development Granger causes economic growth validating supply-side hypothesis in case of Australia. In another study, Hussain and Haque (2016) use the annual data from 1973-2014 for Bangladesh and find that trade and foreign investment variables have a significant impact on the growth rate of GDP per capita. Chakraborty and Mukherjee (2012), in their empirical analysis confirm the long-run cointegrating relationship between FDI, gross fixed capital formation (GFCF) and gross domestic product (GDP) in India. Likewise, in a study on Indonesia, Yusoff and Febrina (2014), find that there exists a long-run relationship among economic growth, domestic investment, real exchange rate and trade openness.

In another study, Dritsakis, Varelas and Adamopoulos (2006), examine empirically the causal relationship among exports, gross capital formation, foreign direct investments and economic growth using a multivariate autoregressive VAR model over the period 1960-2002 for Greece. The results of cointegration test suggested that there is only one cointegrated vector between the examined variables, while Granger causality tests showed that there is a unidirectional causal relationship between exports and gross fixed capital formation and also there is a unidirectional causal relationship between foreign direct investments and economic growth. In a study on the Nigerian economy, Olufemi (2004), use the VECM technique and find that economic growth and openness are cointegrated for the Nigerian economy, thus there is a long-run relationship between them. Only unidirectional causality from economic growth to trade openness was present. Gurgul and Lach (2010) use the quarterly data on Polish economy to examine the linear and non-linear causalities between international trade and economic growth from 1996 to 2009. The results of linear causality tests indicate feedback between the growth rate of exports and growth in gross domestic product (GDP) for both pre and post crisis period. However, the empirical results indicate, no direct causal links between rate 
of growth of GDP and imports. In another study on Bangladesh Manni, Siddiqui and Afzal (2012) investigate the effect of trade liberalization on Bangladesh economy between the periods 1980 to 2010.The empirical findings indicate increase in the rate of growth of GDP consequent to liberalization, consistent with the trade led growth hypothesis. Using the ARDL bounds test, Shahbaz (2012) examines the effect of trade openness on economic growth in the long run using the Cobb-Douglas production function for Pakistan from 1971 to 2011. Empirical results suggest that the variables are cointegrated and trade openness promotes economic growth in the long run. The Granger causality results are in conformity with the growth-led-trade hypothesis.

\subsection{Trade Policy in India}

The changing perception towards the external sector and its role in the overall strategy of development, the policies relating to India's foreign trade have over the years undergone significant changes. The first phase from the time India gained Independence to early 1980s was affected by Soviet planning and adopted an inward looking development strategy wherein import substitution constituted a major element of both trade and industrial policies. This was based on the premise that given the export base it may be difficult for the country to have a growth strategy mainly based on exports. Imports were regulated both by high tariff and quantitative restrictions. Import tariffs, based on the recommendations of the Tariff Commission, were initially used to provide infant industry protection to selected industries. Therefore, trade in India in the late 1970s and early 1980s was based on a complex system of licensing. India's trade policy was primarily based on quotas rather than tariffs. The main drawback of the importsubstituting industrialisation was that, while it encouraged development of industries in the country, it discouraged competition, economic efficiency and expansion of exports. The volume of world exports expanded at an average rate of 7.9 percent annually from 1950-1973, but India's exports grew by only 2.7 percent annually. The share of India's exports in GDP declined from lowest level of 3 percent in 1965 and remained below 4 percent until 1973. This resulted in the declining share of India into the world markets (Srinivasan and Tendulkar, 2003).

During 1980's trade policies were significantly liberalised when licensing and high regulations gave way to a more open regime especially during the second half of the decade. This change was primarily based on the recommendations of various committees that were set up in the 1970's and the 1980's. The two important ones were Committee on Import Export Policies and Procedures (Chairman: P.C. Alexander, 1978) and the Committee on Trade Policies (Chairman: Abid Hussain, 1984). The Alexander 
Committee recommended the simplification of the procedure of import licensing and provided a framework involving a shift in the emphasis from "control" to "development". The Abid Hussain Committee envisaged "growth led exports" rather than "exports led growth" and stressed upon the need for harmonisation of foreign trade policies with other economic policies arguing for a phased reduction of effective protection (Kapila, 2004). Despite these changes, the trade regime in the 1980's continued to be characterised by the overwhelming presence of the licensing mechanism and a high level of tariffs which protected the economy from external competition. In 1990's India experienced large imbalances in its internal and external account. This paved the way for wide ranging reforms in economic policies including its trade policy. Some key measures were taken to create an environment for achieving rapid increase in exports, raising India's share in world's exports and making exports an engine for achieving higher rate of growth. The measures that were taken included rationalisation of exchange rate policy, liberalisation of imports, incentive to exporters and simplification of procedural formalities and fostering of transparency.

In 1991, the rupee depreciated by around $20 \%$ vis-a-vis the basket of five currencies, viz, the US dollar, the Deutschmark, the British pound, the French franc and the Japanese yen (Sharan and Mukherjee, 2001). In the same year partial convertibility of the rupee was introduced through a dual exchange rate system known as the Liberalised Exchange Rate Management System (LERMS). In 1993 rupee was made fully convertible on trade account with the introduction of unified market determined exchange rate system. By August 1994, the rupee was made fully convertible on current account. Liberalisation of imports was considered as pre-requisite for expansion of exports. In 1990-91, the import-weighted average of tariffs for all import stood at $87 \%$ (with tariffs on some imports exceeding 300\%). Import-weighted average tariffs on consumer goods imports were as high as $164 \%$. In addition, some non-tariff barriers, particularly quantitative restrictions applied to virtually all imports. During the decades of reforms, import-weighted average tariffs declined to $24.6 \%$ by $1996-1997$. As of the fiscal year 2000-01, there are just four major tariff categories (35\%, 25\%, 15\% and 5\%), although most imports attract tariffs of $25 \%$ and $35 \%$. Quantitative restrictions (QRs) on most imports have been abolished as of April 1, 2001. However, agricultural sector still remains highly protected, while QRs have been abolished on agricultural imports, tariffs have been raised to high levels.

Between 1980-81 to 1990-91 India's exports increased by 2.14 times rising from $\$ 8486$ million to $\$ 18143$ million. During the same period India's imports increased by 1.5 times rising from $\$ 15869$ million to $\$ 24075$ million. The post reform years (199293 to 2009-10) witnessed a surge in both exports and imports when they increased by 9.6 
times and 13.18 times respectively. In 1992-93 India's exports in value terms were $\$ 18537$ million which increased to $\$ 178751$ million in 2009-10. Imports during the same period increased from $\$ 21882$ million to $\$ 288373$ million (Figure 1). Thus, India's trade performance increased significantly in the post reform period compared to that of pre-reform period. Further within the reform period exports increased by 2.40 times during the sub-period 1992-93 to $2000-01$ and by 4.07 times in the sub-period 2001-02 to 2009-10. The increase in imports during the two sub-periods was 2.30 and 5.60 times respectively (Figure 2). On an average annual basis, export growth during the post reform period at 14 percent was higher than that of 8 percent registered during the pre-reform period. Further within the reform period exports increased by 11 percent per annum during the sub-period 1992-93 to 2000-01 and accelerated to 17 percent per annum in the sub-period 2001-02 to 2009-10. Similarly the average import growth observed during the post reform period at 17 percent was more than double of that recorded in the pre-reform period ( 8 percent). Imports increased at 12 percent per annum during the first sub-period and jumped to the level of 22 percent per annum in the second sub-period. Figure 3 presents exports, imports and trade balance as a share of GDP.

Figure 1: Exports, Imports and Trade Balance (1982-2015)

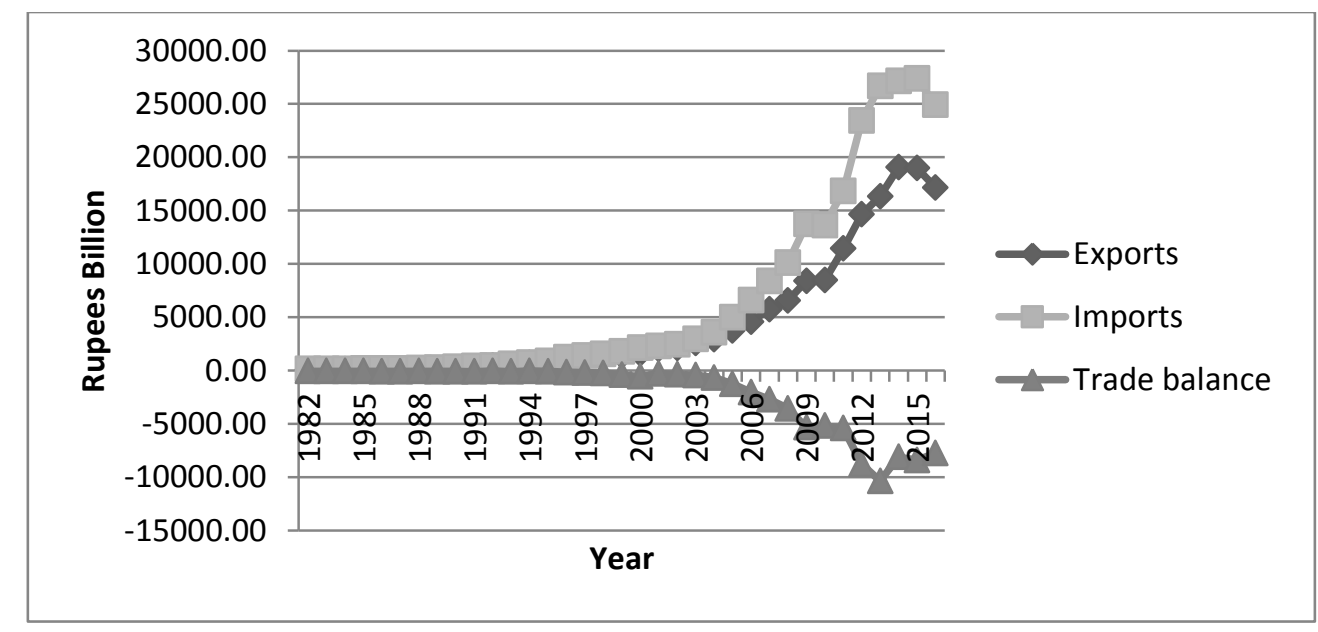

Source: Constructed from RBI data

In recent years, trade initiative has moved towards the Special Economic Zones (SEZ). Intention was to enable exporters to avoid both the bureaucratic red tape governing transactions and the restrictive labour laws. The objective is to promote the development of large-scale manufacturing of unskilled labour-intensive goods. The 
legislations permitting SEZs was passed in 2005 and regulations for implementation was promulgated in early 2006. By end of 2010, a total of 130 SEZs are already exporting. Out of this 75 are information technology (IT) / IT enabled services (ITES), 16 multiproduct and 39 other sectors specific SEZs. The total number of units in these SEZs is 3139.

Figure 2: Rate of Growth of Exports, Imports and GDP (1982-2016)

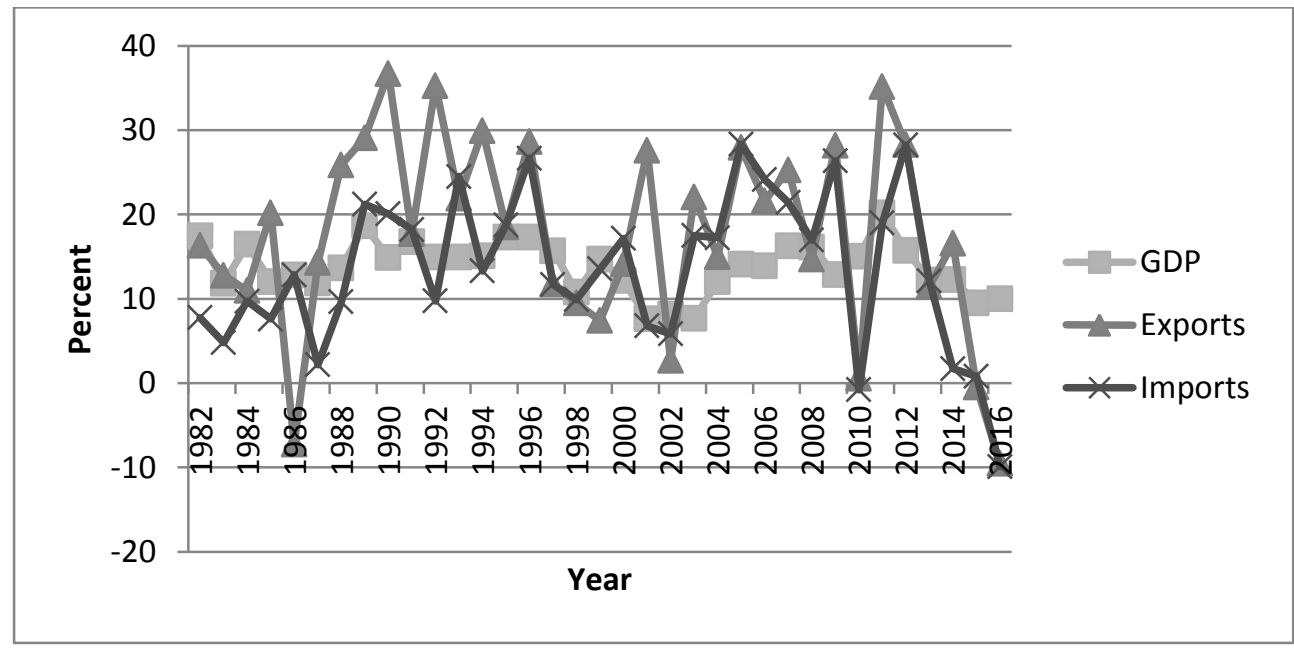

Source: Constructed from RBI data

Figure 3: Exports, Imports and Trade Balance as a share of GDP (1982-2016)

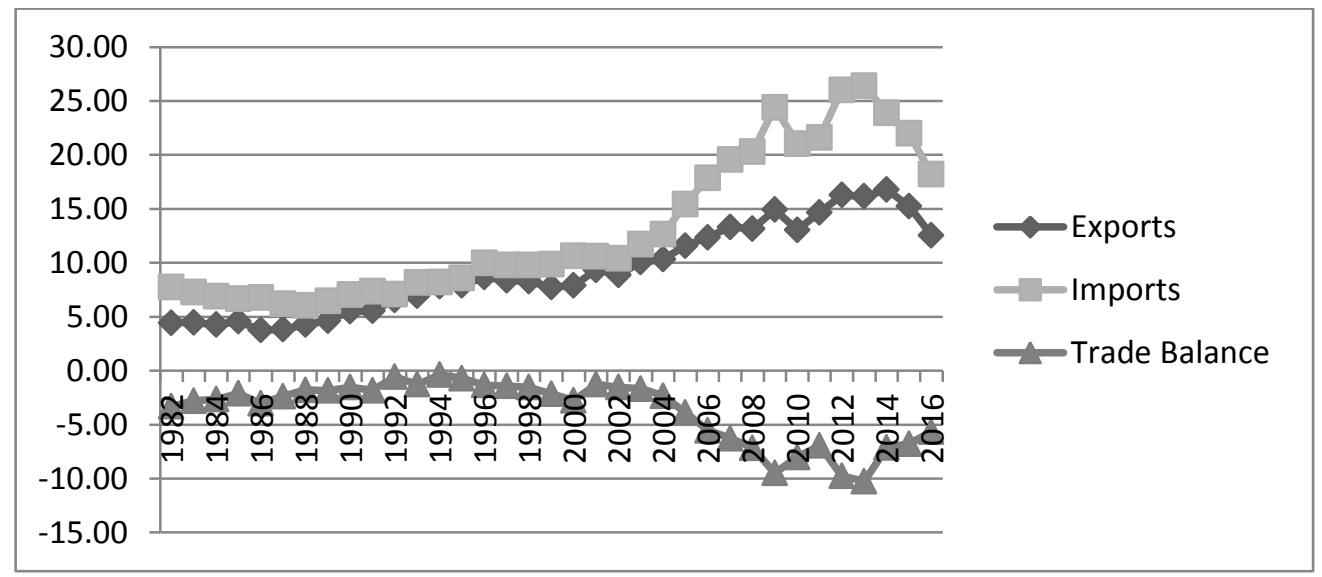

Source: Constructed from RBI data 
34 | PRAGATI: Journal of Indian Economy, Volume 4, Issue 1, January-June 2017

\subsection{Research Methodology}

\subsection{Data and variables}

The current study uses the annual data on India from 1982-2016. The data has been taken from The Database on Indian Economy, provided by the Reserve Bank of India. I have calculated the rate of growth of GDP, exports and imports for India. The objective of the study is to examine the relationship between GDP and exports on one hand and GDP and imports on the other hand. The description of variables is given in Table 1.

\section{Table 1: List of Variables and Sources of data}

\begin{tabular}{|c|l|l|l|}
\hline S. No. & Variable & Description & Data Source \\
\hline 1 & GDP & $\begin{array}{l}\text { Rate of growth of GDP at market } \\
\text { prices }\end{array}$ & $\begin{array}{l}\text { RBI- Database on Indian } \\
\text { Economy }\end{array}$ \\
\hline 2 & Exports & Rate of growth of exports & $\begin{array}{l}\text { RBI- Database on Indian } \\
\text { Economy }\end{array}$ \\
\hline 3 & Imports & Rate of growth of imports & $\begin{array}{l}\text { RBI- Database on Indian } \\
\text { Economy }\end{array}$ \\
\hline 4 & GDPFD & First difference of GDP & $\begin{array}{l}\text { RBI- Database on Indian } \\
\text { Economy }\end{array}$ \\
\hline 5 & ExpFD & First difference of exports & $\begin{array}{l}\text { RBI- Database on Indian } \\
\text { Economy }\end{array}$ \\
\hline 6 & ImpDF & First difference of imports & $\begin{array}{l}\text { RBI- Database on Indian } \\
\text { Economy }\end{array}$ \\
\hline
\end{tabular}

\subsection{Econometric methodology}

To examine the long-run relationship between government spending and economic growth, Johansen cointegration approach has been used. The first step is to check the stationarity properties of the variables using the Augmented Dickey Fuller test and Phillips Perron test. If the variables are integrated of order one, next step is to estimate the rank of the cointegrating equation. To analyse the short run relationship between government spending and economic growth, Granger causality test is applied.

\subsubsection{Unit root tests}

In order to test for cointegration the first step is to check the stationarity properties of the variables. Stationarity is defined as "A stochastic process is said to be stationary if its mean and variance are constant over time and the value of covariance between two 
time periods depends only on the distance or gap or lag between the two time periods and not the actual time at which the covariance is computed" (Gujrati 2004). Augmented Dickey-Fuller (ADF) test and Phillips Perron (PP) test have been used to check if the variables have a unit root. The null hypothesis is that the series is non-stationary and hence contains a unit root.

\subsubsection{Cointegration test}

Two variables are said to be cointegrated if they have a long term or equilibrium relationship between them. There are two time series X and Y and both are I (1), that is they contain a unit root and are integrated of order 1. If we regress $\mathrm{Y}$ on $\mathrm{X}$ (equation 1)

$\mathrm{Y}_{\mathrm{t}}=\mathrm{a}+\mathrm{b} \mathrm{X}_{\mathrm{t}}+\mathrm{u}_{\mathrm{t}}$

$u_{t}=Y_{t}-a+b X_{t}$

Now if we find that $u_{t}$ (Equation 2) is stationary that is integrated of order zero. So both $X_{t}$ and $Y_{t}$ are non-stationary but their linear combination is stationary, that is $1(0)$. In this case $X_{t}$ and $Y_{t}$ are cointegrated.

$\mathrm{ADF}$ and PP test results indicate the all the variables are integrated of order one I (1), so we check if they have a long run relationship between them. Simple regression models assume that variables are covariance stationary, that is its mean and autocovariances are finite and time invariant. Cointegration analysis can be used when variables are not covariance stationary. Most of the economic time series are integrated of order I(1) that is they become stationary after first difference. Standard OLS procedure can't be applied if the variables are not stationary as it results in a spurious regression. In order to test for the cointegration we select the optimal number of lags by using the selection-order criteria such as the sequential likelihood-ratio test (LR), final prediction error (FPE), Akaike's information criterion (AIC), Hannan-Quinn information criterion (HQIC) and Schwarz Bayesian information criterion (SBIC) method. Johansen's test for cointegration begins with a maximum rank of zero that is zero or no cointegrating equations and then accepts the first null hypothesis that is not rejected. There are three methods of determining the number of cointegrating equations using the Johansen methodology. All three methods are based on estimating parameters using the Maximum Likelihood method. The first method is based on a trace statistic, it begins with zero cointegrating equations and then accepts the first value of rank (r) for which trace statistic doesn't reject the null hypothesis. Second method is the maximumeigenvalue statistic. The null hypothesis assumes there are $r$ cointegrating equations and the alternative hypothesis is there are $r+1$ cointegrating equations. The problem with this 
measure is that there is no solution to the multiple testing and hence it is used less than the trace statistic. And the third method is based on minimising the information criterion such as the Schwarz Bayesian information criterion (SBIC), the Hannan and Quinn information criterion (HQIC) and the Akaike's information Criterion (AIC).

\subsubsection{Granger Causality test}

If two variables are cointegrated, we can use the Granger causality test to measure the short run relationship between them. A variable " $y$ " is said to Granger cause variable " $x$ " if, given the past values of $x$, past values of $y$ are helpful in predicting c. One of the ways to test Granger causality is to regress $\mathrm{x}$ on its own past values and past values of $\mathrm{y}$. The null hypothesis is that there is no causality from variable $\mathrm{y}$ to $\mathrm{x}$ that is, we test that the estimated coefficients on the past values of $y$ are jointly zero. If we fail to reject the null hypothesis this implies y does Granger cause $\mathrm{x}$ and hence past values of $\mathrm{y}$ are useful in forecasting $\mathrm{x}$. So there can be a unidirectional causality from variable $\mathrm{y}$ to $\mathrm{x}$ or from variable $\mathrm{x}$ to $\mathrm{y}$, bilateral causality or feedback effects when variable $\mathrm{x}$ causes $\mathrm{y}$ and variable $\mathrm{y}$ also causes $\mathrm{x}$ and if neither $\mathrm{x}$ Granger causes y nor $\mathrm{y}$ Granger causes $\mathrm{x}$, then the two variables are said to be independent or no causality exists between them. The simplest test is to estimate the regression which is based on

$$
x_{t}=c_{1}+\sum_{i=0}^{p} \alpha_{i} x_{t-i}+\sum_{j=1}^{p} \beta_{j} y_{t-j}+u_{t}
$$

using OLS and then conduct a $F$-test of the null hypothesis $H_{0}: \beta_{1}=\beta_{2}=\ldots=\beta_{p}=0$. If Ho is rejected, then y causes $\mathrm{x}$. Likewise, this technique can be used in investigating whether or not $\mathrm{x}$ causes $\mathrm{y}$.

\subsection{Empirical Results}

In this section we examine the empirical results obtained from the data. The first step in estimating the long run relationship between variables is to check if the variables are stationary. Two tests, Augmented Dickey fuller (ADF) test and Phillips Perron (PP) test are used to check for the presence of a unit root. Results from both the tests with intercept and intercept \& time trend indicate that all the variables have a unit root and are integrated of order one I(1) at 5\% level of significance for both ADF and PP test, that is after the variables are differenced once they become stationary (Table 2).

The next step is test for cointegration test to see if the variables have a long term or equilibrium relationship between them. The optimal number of lags are selected using the various criteria such as the sequential likelihood-ratio test (LR), final prediction error (FPE), Akaike's information criterion (AIC), Hannan-Quinn information criterion 
(HQIC) and Schwarz Bayesian information criterion (SBIC) method. According to these criteria optimal lag length is estimated to be two. All three methods in the Johansen methodology have been used to estimate the parameters of the cointegrating equation.

\section{Table 2: Unit Root Test Results}

Null Hypothesis: There is a unit root or non-stationarity

\begin{tabular}{|l|c|c|c|c|c|c|}
\hline \multirow{2}{*}{ Variables } & \multicolumn{3}{|c|}{ ADF Test } & \multicolumn{3}{c|}{ PP Test } \\
\cline { 2 - 7 } & c & c \& t & Conclusion & c & c \& t & Conclusion \\
\hline GDP & -2.32 & -2.417 & $\mathrm{I}(1)$ & -2.94 & -3.401 & $\mathrm{I}(1)$ \\
\hline Exports & -2.034 & -2.011 & $\mathrm{I}(1)$ & $-2.89^{*}$ & $-3.46^{*}$ & $\mathrm{I}(1)$ \\
\hline Imports & -2.487 & -2.21 & $\mathrm{I}(1)$ & $-2.85^{*}$ & $-3.14^{*}$ & $\mathrm{I}(1)$ \\
\hline $\begin{array}{l}\text { Level of } \\
\text { Significance }\end{array}$ & $\begin{array}{r}\text { Critical } \\
\text { Values }\end{array}$ & & & $\begin{array}{l}\text { Critical } \\
\text { Valves }\end{array}$ & & \\
\hline $1 \%$ & -3.696 & -4.306 & & -3.689 & -4.297 & \\
\hline $5 \%$ & -2.978 & -3.568 & & -2.975 & -3.564 & \\
\hline $10 \%$ & -2.62 & -3.221 & & -2.619 & -3.218 & \\
\hline
\end{tabular}

Note: ADF is the Augmented Dickey Fuller Test and PP is the Phillips Perron Test.

$c$ is constant, $c \& t$ is constant and time trend; ***,** and $*$ indicate significance at 1,5 and $10 \%$ respectively.

The first method is based on trace statistic, at $\mathrm{r}=0$, the value of the trace statistic exceed the critical value at 5\% level of significance and hence we reject the null hypothesis of no cointegration. At $r=1$, the value of trace statistic is again more than the critical value at $5 \%$ level of significance and hence we reject the null hypothesis of one or fewer cointegrating equations. So based on the empirical results we find that the two variables, GDP and exports on one hand and GDP and imports on the other hand are cointegrated. The same hold conclusion holds for the cointegartion test based on the maximum-eigenvalue statistic and the information criterion also, there is atleast one cointegrating equation. Therefore, we can conclude that both the GDP and exports \& GDP and imports are cointegrated or there is a long run relationship between the two sets of variables. The Cointegration results are given in Table 3, 4 and 5.

Granger Causality test is used to measure short run relationship between GDP, exports and imports. The results of the results of the Granger causality test are highly sensitive to the lag length and hence, the model is estimated for lag length-2, 3 and 4. Howver, in this study the results for all the three cases gives the same conclusion. The empirical results indicate no causality from exports to GDP and imports to GDP. However, we fail to reject the null hypothesis of no causality from GDP to exports and 
38 | PRAGATI: Journal of Indian Economy, Volume 4, Issue 1, January-June 2017

GDP to imports. Hence lagged values of GDP are useful in predicting exports and imports, consistent with the hypothesis of growth led exports and imports. The results are reported in Table 6 .

Table 3: Johansen Test for Cointegration using the Multiple-Trace Test Method

Null Hypothesis: There are no more than $r$ cointegration relations (starts with $r=0$ )

\begin{tabular}{|l|c|c|c|}
\hline & Maximum Rank & Eigenvalue & Trace Statistic \\
\hline GDP and Exports & 0 & & $38.4992^{* * *}$ \\
\hline & 1 & 0.60172 & $7.1991 * * *$ \\
\hline GDP and Imports & 0 & 0.19082 & \\
\hline & 1 & & $25.8582 * * *$ \\
\hline & 2 & 0.40929 & $7.9594 * * *$ \\
\hline & Rank & $\mathbf{5} \%$ critical value & $\mathbf{1 \%}$ critical value \\
\hline & 0 & 15.41 & 20.04 \\
\hline
\end{tabular}

Note: $C E(s)$ is the number of cointegrating equations, ** and * indicate significance at $1 \%$ and $5 \%$ respectively.

Table 4: Johansen Test for Cointegration using the Maximum-Eigen value Statistic

Null Hypothesis: There are no more than r cointegration relations (starts by assuming a given value of $r$

\begin{tabular}{|l|c|c|c|}
\hline & Maximum Rank & Eigenvalue & Max Statistic \\
\hline GDP and Exports & 0 & & $31.3001 * * *$ \\
\hline & 1 & 0.60172 & $7.1991 * * *$ \\
\hline GDP and Imports & 2 & 0.19082 & \\
\hline & 1 & & 17.8988 \\
\hline & 2 & 0.40929 & 7.9594 \\
\hline & Rank & $\mathbf{5 \%}$ critical value & $\mathbf{1 \%}$ critical value \\
\hline & 0 & 14.07 & 18.63 \\
\hline & 1 & 3.76 & 6.65 \\
\hline
\end{tabular}

Note: $C E(s)$ is the number of cointegrating equations, ** and * indicate significance at $1 \%$ and $5 \%$ respectively. 
Table 5: Johansen Test for Cointegration by Minimizing an Information Criterion

\begin{tabular}{|l|c|c|c|c|c|}
\hline & Maximum Rank & Eigenvalue & SBIC & HQIC & AIC \\
\hline GDP and Exports & 0 & & 13.4652 & 13.40603 & 13.37541 \\
\hline & 1 & 0.60172 & $12.85575^{*}$ & $12.70784^{*}$ & 12.63129 \\
\hline & 2 & 0.19082 & 12.74773 & 12.57023 & 12.47837 \\
\hline GDP and Imports & 0 & & 12.58373 & 12.52457 & 12.49395 \\
\hline & 1 & 0.40929 & $12.36845^{*}$ & $12.22053^{*}$ & 12.14398 \\
\hline & 2 & 0.20872 & 12.23806 & 12.06057 & 11.96871 \\
\hline
\end{tabular}

Note: SBIC is Schwarz Bayesian information criterion, HQIC is Hannan and Quinn information criterion and AIC is the Akaike information criterion. * indicates the minimum value of the information criterion

Table 6: Granger Causality Test Results

\begin{tabular}{|l|c|c|c|c|c|c|}
\hline Lag Length & \multicolumn{2}{|c|}{2} & \multicolumn{2}{c|}{3} & \multicolumn{2}{c|}{4} \\
\hline Null Hypothesis & F-Value & p-value & F-Value & p-value & F-Value & p-value \\
\hline $\begin{array}{l}\text { No causality from } \\
\text { Exports to GDP }\end{array}$ & 0.26179 & 0.7716 & 0.28677 & 0.8345 & 0.25231 & 0.905 \\
\hline $\begin{array}{l}\text { No causality from } \\
\text { GDP to Exports }\end{array}$ & $8.7705^{* * *}$ & 0.0012 & $5.4548 * * *$ & 0.0053 & $3.2936 * *$ & 0.0304 \\
\hline $\begin{array}{l}\text { No causality from } \\
\text { Imports to GDP }\end{array}$ & 0.29969 & 0.7435 & 0.16274 & 0.9204 & 0.32398 & 0.8587 \\
\hline $\begin{array}{l}\text { No causality from } \\
\text { GDP to Imports }\end{array}$ & $7.9192 * * *$ & 0.002 & $6.3801 * * *$ & 0.0025 & $4.7811^{* * *}$ & 0.0067 \\
\hline
\end{tabular}

Note: *** and **,* indicate significance at $1 \%, 5 \%$ and $10 \%$ respectively.

\subsection{Conclusion}

The current study investigates the relationship between exports, imports and economic growth for India using the annual data over the period 1982 to 2016. The empirical findings give mixed results. Through this paper I examine the four relationsexport-led growth, according to this hypothesis a country economically grows only after opening its policy for international trade and increases the volumes of its imports, the opposing theory is the growth-led exports, the hypothesis states that a country can increase its exports only after reaching certain level of development and that the reasons for growth can only come from factors within the country, the third theory for growth is imports-led growth which states that an economy grows only after increase in imports of new technology and resources from abroad. The last theory, growth-led imports supports 
the hypothesis that imports increase only after an increase in the GDP of a country. India's trade policy has gone through significant changes ranging from inward looking, import substitution to export promotion and increasing amounts of FDI and FII flows.

Firstly, the variables are examined for the presence of a unit root using the Augmented Dickey Fuller test and the Phillips Perron test. All the three variables GDP, exports and imports are found to be integrated of order one I(1). In order to investigate the long longrun equilibrium relationships among these variables Johansen cointegration test analysis is carried out. The statistical evidence suggests there is long run relationship between GDP, exports and imports in India. Granger causality test is employed to analyze the short run relationship between GDP, exports and imports. The test has been carried out at lag length 2, 3 and 4 as the results are fund to be sensitive to the lag length. In all the three cases, results support unidirectional causality from GDP to exports and GDP to imports. However, there is no empirical evidence to support Granger causality from exports or imports to GDP. Hence, the results in this paper are in conformity with growth-led trade hypothesis. That is, that economy's GDP can grow only from forces originating within the country itself.

The empirical findings support both the hypothesis: growth-led exports, which states that only after a country reaches certain level of economic development, satisfies demand in its domestic market, it can start exporting its products; and growth-led imports proposition, that is, import demand increases as an economy becomes economically advanced. As a country grows, the demand for imports increases as consumers want to consume a greater variety of goods and services.

\section{References}

Bhattacharya, M., \& Bhattacharya, S.N. (2016). International trade and economic growth: Evidences from the BRICS. Journal of Applied Economics and Business Research JAEBR, 6(2),150-160.

Chakraborty, M. \& Mukherjee, J. (2012). Is there any relationship between foreign direct investment, domestic investment and economic growth in India? A time series analysis. Review of Market Integration, 4(3), 309-337.

Dixit, A. \& Stiglitz, J. (1977). Monopolistic competition and optimum product diversity. American Economic Review, 67(3), 297-308. 
Dritsakis, N., Varelas, E., \& Adamopoulos, A. (2006). The main determinants of economic growth: An empirical investigation with Granger causality analysis for Greece. European Research Studies, 9(3-4), 47-58.

Dritsakis, N. (2006). Exports and economic growth: An empirical investigation of EU, USA and Japan using causality tests. International Review of Applied Economic Research, 1(2), 79-92.

Emma, S. (2005). Openness and growth: An empirical investigation. Human Development Report Office Occasional Paper, Human Development Report 2005.

Frankel, J. \& Romer, D. (1996). Trade and growth: An empirical investigation. National Bureau of Economic Research, Working Paper No. 5476, March.

Gujrati, D.N. (2004). Basic econometrics, (4th Ed.), New York, USA: The McGraw-Hill Companies.

Gurgul, H \& Lach, L. (2010). International trade and economic growth in the Polish economy. Munich Personal RePEc Archive, Paper No.52286.

Helpman, E. \& Krugman, P.R. (1985). Market structure and foreign trade: Increasing returns, imperfect competition and the international economy. Cambridge, MA, MIT Press.

Hussain, M.E. \& Haque, M. (2016). Foreign direct investment, trade, and economic growth: An empirical analysis of Bangladesh. Economies, 4(7), 1-14.

Kapila, U. (2004). Foreign trade and balance of payments. In Uma Kapila (ed), Indian Economy Since Independence, pp. 526. New Delhi: Academic Foundation.

Krugman, P.R. (2015). International economics: Theory and policy. Pearson Global Edition, $10^{\text {th }}$ Edition.

Makki, S. \& Somwaru, A. (2004). Impact of foreign direct investment and trade on economic growth: Evidence from developing countries. American Journal of Agricultural Economics, 86(3), 795-801. 
42 | PRAGATI: Journal of Indian Economy, Volume 4, Issue 1, January-June 2017

Manni, U., Siddiqui, S., \& Afzal, M.N. (2012). An Empirical Investigation on Trade Openness and Economic Growth in Bangladesh Economy. Asian Social Science, 8 (11), 154-158.

McDermott, J.F.M. (2011). Chamberlin and Robinson: Their realism revisited and revised. Journal of Post Keynesian Economics, 34(1), 159-178.

Melitz, M.J. (2003). The impact of trade on intra-industry reallocations and aggregate industry productivity. Econometrica, 71(6), 1695-1725.

Muhammad, S., Muhammad, M.R. \& Abdul, F. (2012). Financial development, international trade and economic growth in Australia: New evidence from multivariate framework analysis. Munich Personal RePEc Archive, Paper No. 42023.

Olufemi, S.M. (2004). Trade openness and economic growth in Nigeria: Further evidence on the causality issue. Department of Economics, Obafemi Awolowo University, SAJEMS NS 7, No 2.

Romer, P.M. (1989). Endogenous technological change. National Bureau of Economic Research, Working paper No.3210.

Shahbaz, M. (2012). Does trade openness affect long run growth? Cointegration, causality and forecast error variance decomposition tests for Pakistan. Munich Personal RePEc Archive, Paper No. 37391.

Srinivasan, T.N (2001). India's reform of external sector policies and future multilateral trade negotiations. Economic Growth Centre Discussion Paper No.830, Yale University, June.

Srinivasan, T.N. \& Tendulkar, S.D. (2003). Reintegrating India with the world economy. New Delhi, Delhi: Oxford University Press.

Yusoff, B. \& Febrina, I. (2014). Trade openness, real exchange rate, gross domestic investment and growth in Indonesia. Margin-The Journal of Applied Economic Research, 8(1), 1-13. 